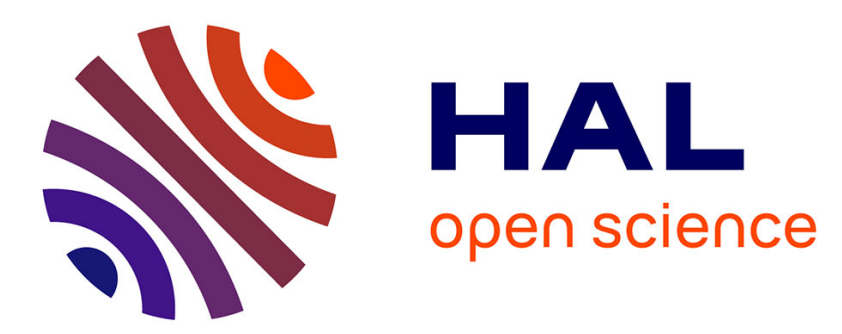

\title{
Prognostic value of the quality indicator "concurrent use of three or more psychotropic drugs" among residents of long-term-care facilities
}

\author{
J. Simon Bell, Heidi T. Taipale, Helena Soini, Kaisu H. Pitkälä
}

\section{- To cite this version:}

J. Simon Bell, Heidi T. Taipale, Helena Soini, Kaisu H. Pitkälä. Prognostic value of the quality indicator "concurrent use of three or more psychotropic drugs" among residents of long-term-care facilities. European Journal of Clinical Pharmacology, 2009, 65 (11), pp.1163-1164. 10.1007/s00228009-0689-5 . hal-00534976

\author{
HAL Id: hal-00534976 \\ https://hal.science/hal-00534976
}

Submitted on 11 Nov 2010

HAL is a multi-disciplinary open access archive for the deposit and dissemination of scientific research documents, whether they are published or not. The documents may come from teaching and research institutions in France or abroad, or from public or private research centers.
L'archive ouverte pluridisciplinaire HAL, est destinée au dépôt et à la diffusion de documents scientifiques de niveau recherche, publiés ou non, émanant des établissements d'enseignement et de recherche français ou étrangers, des laboratoires publics ou privés. 


\title{
Prognostic value of the quality indicator "concurrent use of three or more psychotropic drugs" among residents of long-term-care facilities
}

\author{
J. Simon Bell • Heidi T. Taipale • Helena Soini • \\ Kaisu H. Pitkälä
}

Received: 5 June 2009 /Accepted: 23 June 2009/Published online: 14 July 2009

(C) Springer-Verlag 2009

To the Editor:

We commend Lesén et al. [1] for their excellent research investigating whether the quality indicator "concurrent use of three or more psychotropic drugs" captures use of potentially inappropriate psychotropic drugs (PIPs). Lesén et al. used explicit (or criterion-based) indicators proposed by the Swedish National Board of Health and Welfare to determine PIPs [2]. Explicit indicators can be used in conjunction with large data sets. However, possible limitations of explicit indicators, as acknowledged by Lesén et al., include their limited transferability, lack of consideration

\footnotetext{
J. S. Bell $(\bowtie) \cdot$ H. T. Taipale

Kuopio Research Centre of Geriatric Care, University of Kuopio, P.O. Box 1627, Kuopio 70211, Finland

e-mail: simon.bell@uku.fi
}

J. S. Bell $•$ H. T. Taipale

Department of Pharmacology and Toxicology,

University of Kuopio,

Kuopio, Finland

J. S. Bell $\cdot$ H. T. Taipale

Division of Social Pharmacy, Faculty of Pharmacy,

University of Helsinki,

Helsinki, Finland

H. Soini

City of Helsinki, Health Centre, Social Services,

Helsinki, Finland

K. H. Pitkälä

Unit of General Practice, Helsinki University Hospital,

Helsinki, Finland

\section{K. H. Pitkälä}

Department of General Practice and Primary Health Care, Faculty of Medicine, University of Helsinki,

Helsinki, Finland given to comorbid disease, and limited or unknown ability to predict poor health outcomes $[3,4]$. There is no evidence that potentially inappropriate drug use defined using Beers Criteria, the most widely cited explicit indicators, is associated with mortality or hospitalization among nursinghome residents [5]. Evidence with respect to the association between quality of life and costs among communitydwelling older people is inconclusive. With this in mind, we sought to complement the research of Lesén et al. by analyzing whether the quality indicator predicts 5 -year allcause mortality among residents of long-term-care facilities.

Cross-sectional data were obtained from all 53 long-term care wards in Helsinki, Finland, over a 2-week period in September 2003 [6]. Of 1,444 eligible residents, 1,087 residents or their proxies provided consent to participate. All medication and diagnostic data were extracted from residents' medication charts by trained nurses. Medication, diagnostic, and mortality data were available for 1,004 residents. All regularly used drugs were classified according to the Anatomical Therapeutic Chemical Classification System (drugs used "when required" were excluded). Psychotropic drugs included antidepressants, antipsychotics, anxiolytics, and sedative-hypnotics. Five-year mortality data were obtained from central registers. Cox proportional hazards analysis was used to model the prognostic significance of the quality indicator. Three models were estimated: the unadjusted risk of mortality; the risk of mortality adjusted for age, gender, and Charlson's comorbidity index (CCI); and the risk of mortality adjusted for age, gender, CCI, nutritional status (assessed using the Mini-Nutritional Assessment), and mobility (assessed as a dichotomous variable). The project was approved by the Helsinki University Hospital Research Ethics Committee.

The mean age of the 1,004 residents was 81.3 [standard deviation (SD 10.9)]. Of these, $75 \%$ were women, $58 \%$ had 
Table 1 Risk of 5-year, allcause mortality associated with the quality indicator "concurrent use of three or more psychotropic drugs"

$H R$ hazard ratio, $C I$ confidence interval, $C C I$ Charlson's comorbidity index, MNA Mini-

Nutritional Assessment

\begin{tabular}{|c|c|c|c|c|c|c|}
\hline & \multicolumn{2}{|c|}{ Model 1} & \multicolumn{2}{|c|}{ Model 2} & \multicolumn{2}{|c|}{ Model 3} \\
\hline & HR & $95 \% \mathrm{CI}$ & HR & $95 \%$ CI & HR & $95 \%$ CI \\
\hline Indicator & 0.92 & $(0.78-1.09)$ & 1.09 & $(0.92-1.29)$ & 1.16 & $(0.97-1.38)$ \\
\hline Age & & & 1.04 & $(1.03-1.05)$ & 1.04 & $(1.03-1.05)$ \\
\hline Male gender & & & 1.24 & $(1.04-1.49)$ & 1.29 & $(1.08-1.54)$ \\
\hline $\mathrm{CCI}$ & & & 1.06 & $(1.02-1.11)$ & 1.06 & $(1.01-1.11)$ \\
\hline MNA & & & & & 1.49 & $(1.29-1.72)$ \\
\hline Mobility & & & & & 0.76 & $(0.62-0.93)$ \\
\hline
\end{tabular}

a primary school education or less, and $46 \%$ were widowed. The mean number of regularly used drugs was 7.1 (SD 3.4), and 31\% of residents used nine or more drugs. Among the residents, $76 \%$ used one or more psychotropic drug, $49 \%$ used two or more psychotropic drugs, and $22 \%$ used three or more psychotropic drugs. At the 5-year follow-up, $80 \%$ of residents who used 0-2 psychotropic drugs were deceased compared with $78 \%$ of residents who used three or more psychotropic drugs. Concurrent use of three or more psychotropic drugs was not associated with an increased risk of mortality (Table 1).

Our analyses revealed the quality indicator was not associated with increased mortality. This was despite having high statistical power and adjusting using covariates previously associated with mortality. Our cohort comprised residents who were primarily frail, immobile, diagnosed with dementia, and at high risk of mortality. This population was different to most others in which the risk of mortality associated with atypical antipsychotics has been observed [7]. Our research may not be generalizable to all populations of older people. Hartikainen et al. reported that concurrent use of two or more psychotropic drugs by primarily community-dwelling older people with dementia was associated with an increased risk of 5-year mortality when adjusted for age and gender [8]. The value of the quality indicator may depend on the specific population to which it is applied. When considered together with the findings of Lesén et al., our data highlight the need for urgent research into which quality indicators have prognostic value for poor health outcomes.

\section{References}

1. Lesén E, Petzold M, Andersson K, Carlsten A (2009) To what extent does the indicator "concurrent use of three or more psychotropic drugs" capture use of potentially inappropriate psychotropics among the elderly? Eur J Clin Pharmacol 65:635642

2. National Board of Health and Welfare (2003) Indicators for evaluation of the quality in drug use among the elderly: proposal from the National Board of Health and Welfare [in Swedish] Report number 2003-110-20. Stockholm, Sweden

3. Hamilton HJ, Gallagher PF, O'Mahony D (2009) Inappropriate prescribing and adverse drug events in older people. BMC Geriatr 9:5

4. Spinewine A, Schmader KE, Barber N et al (2007) Appropriate prescribing in elderly people: how well can it be measured and optimised? Lancet 370:173-184

5. Jano E, Aparasu RR (2007) Healthcare outcomes associated with Beers Criteria: a systematic review. Ann Pharmacother 41:438-447

6. Suominen MH, Sandelin E, Soini H, Pitkälä KH (2009) How well do nurses recognize malnutrition in elderly patients? Eur J Clin Nutr 63:292-296

7. Schneider LS, Dagerman KS, Insel P (2005) Risk of death with atypical antipsychotic drug treatment for dementia: meta-analysis of randomized placebo-controlled trials. JAMA 294:1934-1943

8. Hartikainen S, Rahkonen T, Kautianen H, Sulkava R (2005) The use of psychotropics and survival in demented elderly individuals. Int Clin Psychopharmacol 20:227-231 